\title{
Where Do You Go To?: The Class of '76
}

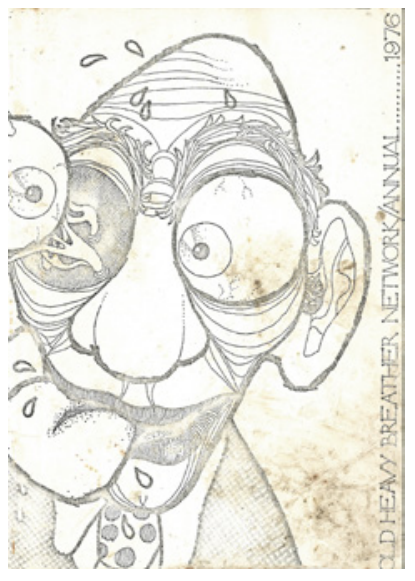

Fig. 1 The Auckland School's Old Heavy Breather Network/Annual, 1976. [Cover graphic by Geoff Fletcher]
In 1976, each student in the University of Auckland School of Architecture received a booklet (see Fig. 1) with the names, addresses and phone numbers of all the students (Auckland School of Architecture 1976). Spread across the four professional years of the degree are 310 people, 74 of whom were first-year students, including the author. This article tracks that first-year cohort over the 40-plus years since; a time span that gives an opportunity to trace the ins and outs, and ups and downs of architectural study and careers. It also allows the outcomes of this cohort to be compared with available statistical data (including some incomplete data from the 1978 and 1980 student contacts booklets) to help test and understand that data.

There has traditionally been a mismatch between the social stereotypes of architects held by the public and the actuality of being an architect, which means that many students who begin architectural study do not complete it (Cuff 1991: 117). For those who graduate and wish to participate in the profession, economic and other conditions sometimes render a continuing career in architecture difficult. So, what happened to the first-year students of 1976, and how might their journeys illustrate the complexities of architecture, its education, and practice?

\section{In 1976}

The School of Architecture at the University of Auckland was established in 1917 and was until the mid-1970s the only school in New Zealand. Those arriving in 1976 came into a School that had recently had its "narrow" professional training focus questioned by student protest in 1972, which subsequently ushered in a wider range of course content and options (Francis 2016).

This period at the School is described by Bill McKay in the formal history of the School as "the loose years", marked by hippiedom and a somewhat anti-intellectual kind of humanism (McKay 2017: 98). Perhaps one sign of that looseness is the contacts booklet itself. Twenty-first-century privacy legislation means that such a document would be very unlikely to be formally distributed today. Even in the 1970s, there must have been some awareness of the potential for the booklet to permit both privacy invasion and unsavoury behaviour because it is titled "Old Heavy Breather Network/Annual", and the cover graphic by Geoff Fletcher 
(a final-year student in 1976) of an eye-popping, salivating, archetypal "dirty old man" leaves little to the imagination. ${ }^{1}$

Protests in architectural schools across the world of the like that occurred in Auckland in 1972 were not unusual at this time when the post-war consensus that modernism was the best (only) basis for an architectural education was seriously and, at times, aggressively challenged. As Mary McLeod argues for North America, all architecture schools there were affected by the convulsions caused by the civil rights movement, anti-Vietnam war protests, and second-wave feminism (McLeod 2012: 163). Separately, and collectively, these led to the questioning of many aspects of architecture including its role in the exploitation of resources and people (Francis 2016: 282), and its alliance with power elites (McLeod 2012: 163).

The impact of feminism was particularly visible in one of the most notable characteristics of the 1976 first-year intake: the number of women. Of the 74 students, 24 (very nearly one-third) were female. At the newly opened Victoria University of Wellington School of Architecture women were similarly around one-third of their intake (D. Cranko, personal communication, September 11, 2017).

The 1970s saw significant growth in the number of women entering and succeeding in professional education across the world. Unpacking the situation in the United States, Stacey Jones argues that a complex combination of socio-economic shifts in the late 1960s and early 1970s contributed to rocketing female enrolments in professional schools (Jones 2011). These included changing and loosening expectations of women's role in society, the availability of reliable contraception, a decline in demand in the teaching profession (the traditional destination for most university-educated women), and civil rights legislation leading to a broadening of challenges to all discrimination, including that of gender. In 1972, those challenges resulted in a ruling that rendered blocking the entry of women into education programmes funded by the U.S. federal government illegal (as cited in Stratigakos 2016: 21). Jones maintains that once in the professional schools, women attained a critical mass that made previous deterrent factors, such as isolation and discrimination, less sustainable (Jones 2011: 349). The effect of all these shifts and changes is clearly visible in the composition of graduates of U.S. architecture schools over the decade: in 1970, women made up a low approximately $7 \%$ of graduates, but by 1979 that figure had jumped to $27 \%$ (Stevens 2014).

In New Zealand, there was also a particular structural/cultural impediment to women entering the University of Auckland's School of Architecture. From 1961 to 1970, candidates for architecture were required to complete an intermediate year comprising Physics plus two subjects from a prescribed but broad list of offerings from across the University (University of Auckland 1961: 308; University of Auckland 1969: 451). At the time, many all-girl schools in New Zealand did not offer Physics as part of their curriculum, nor was it a particularly popular subject for girls in co-ed schools where it was on offer. Physics was, at the time, simply not seen as a "suitable" subject for girls to study. This cultural norm interacted with the structural condition to form an impediment to women entering architecture, because without a foundation in Physics at high-school level, success in the subject at University level was difficult. However, from 1971 candidates for architecture selected one subject from each of three groupings, and Physics was 
grouped with Mathematics and Applied Mathematics (University of Auckland 1970: 492). With Physics now optional, more women were able to successfully complete the intermediate and apply for the four professional years of study at the School of Architecture. This single change in the entry requirements strongly contributed to a significant jump in the number of women accepted into the School in 1972, from a handful a year (if any) to double digits for the first time: 13 out of approximately 70, or 18\% (Civil 2016).

Fig. 2 shows the depressing effect this combined structural and cultural barrier had on the proportion of women graduates from the school over the decade it was in place, and their rise once this (and other constraints) were removed. The latest figures show women comprising around $60 \%$ of the Auckland School's graduates, a figure that is much higher than the $51 \%$ average for the three New Zealand schools (Australian Institute of Architects 2015). Auckland is also an outlier among schools of architecture in Australasia (average 47\% in 2014), the United Kingdom (41\% in 2014-15) (Mirza \& Nacey Research 2017), and the United States (44\% in 2012) (Stratigakos 2016: 21).

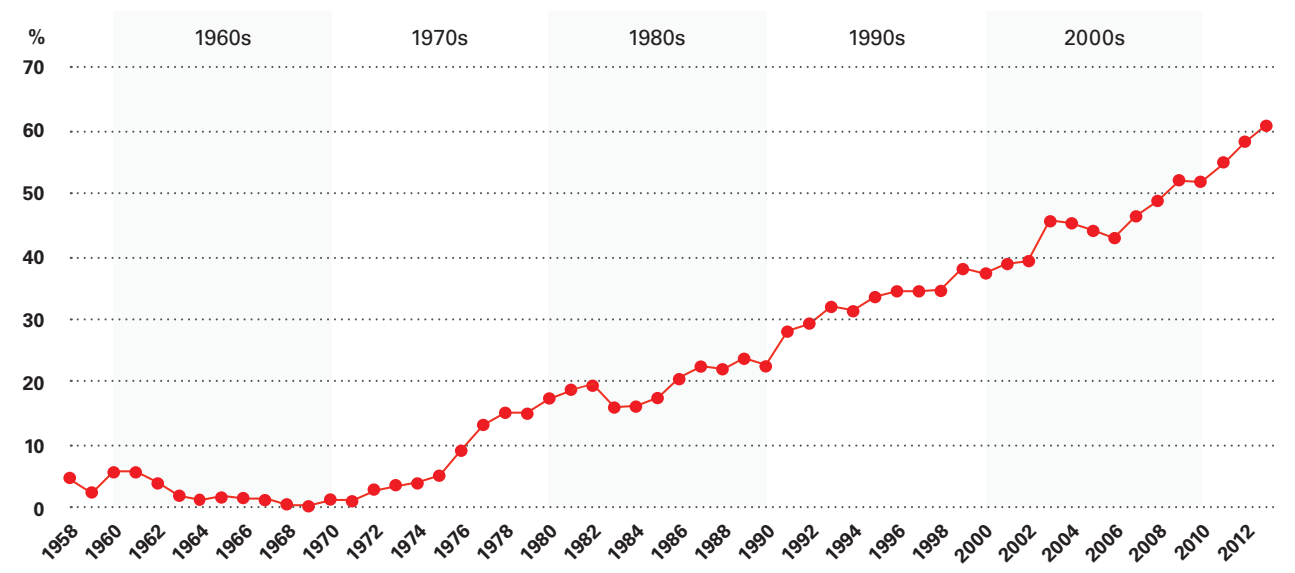

Fig. 2 Proportion of female graduates from the Auckland School of Architecture (known since 2006 as the School of Architecture and Planning). The data have been "smoothed" by taking the average for the year plus the previous two years. Smoothing evens out abrupt year-onyear changes and allows the overall pattern to be discerned. [Sources: University of Auckland Calendar (1958-61); University of Auckland Convocation for the Conferment of Degrees and Diplomas (1959-98); and Architecture Schools of Australasia (2001-15)]
The high number of women (24 or 32\%) in the 1976 first-year intake did not, however, signal a trend. The 1978 and 1980 student contacts booklets give partial information on the gender makeup of the School in those years as, unlike the 1976 booklet, full names are not given in these years except for the first-year class of 1978. In 1978, there were just 12 women out of 71 accepted (Auckland School of Architecture 1978) - half the 1976 figure and similar to the 1972 intake. Women were approximately $21 \%$ of the first years in $1980-57$ of the 70 are gender-identifiable, 12 of whom are women (Auckland School of Architecture 1980).

The high number of women in the 1976 intake meant that women's proportion of the School's students that year lifted to over $20 \%$ for the first time (65 of the 310) (Auckland School of Architecture 1976). The School as a whole roughly kept this proportion into 1978 (299 students, with 60 women out of the 287 who are gender-identifiable), mainly because many of the 1976 intake were still present at the School, now in their third year. However, by 1980, the proportion of women dropped to under 20\% (approximately 18\%; 290 students with 48 of the gender-identifiable 264 being women).

The high number of women in first-year architecture in 1976 was so unusual that some featured in an article (see Fig. 3) in the Auckland Star (Untitled 1976), 
where the novelty of women on a building site (albeit a training one) posing with hammers was indicative of the changing nature of sex roles over the decade-notwithstanding the condescending comments of the Head of Carpentry at Carrington Technical Institute in the accompanying text. The following Sunday, another member of the class was also pictured in a newspaper as the naked "Sunday Male" in the weekly tabloid Sunday News (1976)-another indication of the changing social attitudes towards gender of the decade.

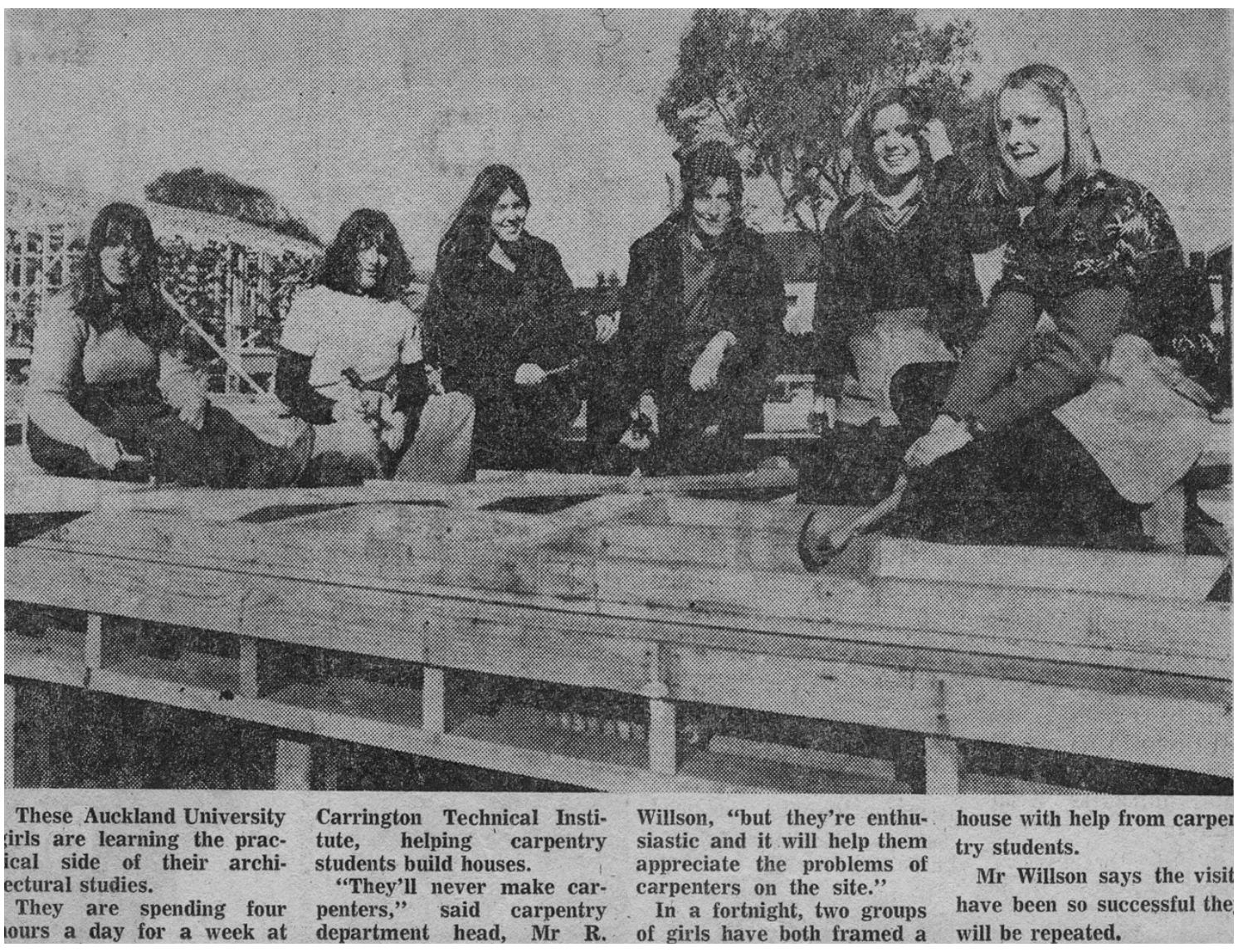

Fig. 3 Women architecture students profiled in the Auckland Star, August 9, 1976, p. 5. [Stuff/Auckland Star]
Acceptance into the School and successful completion are two separate matters. By the end of 1976, 11 of the 74 (or 15\%) had not been successful in first-year studio, according to the passes published in the New Zealand Herald (University Passes, Studio I 1976), which appear to be reasonably accurate. Some of those who successfully completed the year did not continue, and at least three who were not successful or dropped out, returned. By the beginning of 1978, another 15 of the 74 (a further $20 \%$ ) had either failed or decided not to continue with their studies in architecture.

Class cohort sizes fluctuated from one year to the next with some students joining (or leaving) through repeating a year, or returning after some time out, either working in an office, travelling, or both. While a year out working was a requirement in many architecture degrees in Australia at the time, this was not the case in New Zealand. There was little financial or academic penalty involved in breaking continuity of study in whatever manner, because tertiary education was in effect free and students were well supported. Some also entered the degree with advanced standing, such as those with the New 
Zealand Certificate in Draughting who were exempted from the intermediate and first professional year (University of Auckland 1976: 354). Consequently in 1977, approximately a dozen "draughties" joined the cohort's second year.

These movements meant that by 1978 , in the third professional year of the degree, there were 79 in the year group, 42 (or 57\%) of whom were from the first-year class of 1976. Another eight of the original cohort took some time out in 1978, but returned to complete the degree at a later date. According to the passes listed in the New Zealand Herald, 18 of that third-year cohort, or nearly one-quarter (23\%), were not successful (University Passes, Studio 3 1978). This was an abnormally high failure rate for the School; my recollection, and that of my peers, is that this failure level came as a great shock. The high level of failure can be seen when compared with the third years in 1976 and 1980 of 17\% and 16\% respectively (University Passes, Studio III 1976; University Passes, Studio 3 1980).

By the mid-1970s, due to pressures on space and the 1972 shake up of the School, studio teaching was divided into three sub-schools, each with a different pedagogical philosophy and design programme. This variety was a result of, and contributed to, the "looseness" of the School, which meant there was an eclectic openness to different ways of teaching. The sub-schools were named after the construction of the building in which they were housed and, roughly speaking, Timber Studio was conservative and profession focused, Brick was highly experimental including vertical studios, and Steel was somewhere in between (McKay 2017: 81-84). Member of staff John Hunt describes some of the meetings for moderating student studio grades becoming battlegrounds for the differing philosophies (as cited in McKay 2017: 98). Many in the cohort believed that those who were victims of the high failure rate in 1978 were the collateral damage of these battles where scores were settled, and results bore little relationship to students' ability. Given that two-thirds of the 18 who failed returned, graduated, and have become successful and award-winning architects, there is perhaps some merit in that belief.

Critically, the shock of failure was not evenly spread across the cohort: as cohort member Anna Kemble Welch pointed out to me, women were particularly targeted (A. Kemble Welch, personal communication, July 11, 2017). Women comprised 11 (or 61\%) of the 18 not-successful/failed in 1978 and thus were disproportionally represented in this group. As a result, by the end of 1978, women fell from constituting one-third of the year group to one-quarter. In 1976 and 1980, third-year women also had a higher failure rate than their proportion in the class, but not nearly as disproportionate as in 1978 - in both years, women comprised $16 \%$ of the year, 14 students were not successful, three (or $21 \%$ ) of whom were women. Women did, however, comprise eight of the 12 who returned after their failure in 1978 to repeat the year and graduate. But two transferred to the School of Architecture at Victoria University to do so. Of the 310 students listed in the 1976 contacts booklet, 252 eventually graduated, three from Victoria and these three were all women.

Kemble Welch explicitly transferred to the Wellington School because of the presence of two female staff there-Wendy Light and Helen Tippett (A. 
Kemble Welch, personal communication, July 11, 2017). In contrast, there were none at the much larger Auckland School, where the first female staff member, Sarah Treadwell, was not appointed until 1981 (Barrie 2017: 103). Earlier in the School's history, women starting architecture study were told that many of them would drop out, and/or that they could be a woman or an architect but not both (Matthewson 2010: 178). Such overt discrimination (often delivered under the guise of "friendly advice") was perhaps less prevalent by the late 1970s, but clearly the path for the women students at the time was not unproblematic, despite their increased numbers.

\section{Graduation}

Of that first-year class of 1976, 47 of the 74 (or 64\%) graduated with a degree in architecture (University of Auckland 1959-1994). Of the 27 who did not, 24 had decided to leave study sometime within the first two years of the fouryear professional degree. These non-graduates went into careers including art, book illustration, maths, accountancy, draughting, property and project management, and social work. Juliet Newson switched to geology and was the president of the International Geothermal Association from 2013 to 2016 (Twose 2015). At least two-Jackie Gilmore and Phillip Thomass-went into the film industry. Gilmore was the assistant art director for the multi-award-winning New Zealand movie, The Piano ("Jackie Gilmore" n.d.). A move into film for those who had studied or graduated from architecture was not unusual at this time before there were qualifications in film in New Zealand. At least another four people listed in the 1976 contacts booklet have had very successful careers in film-Stuart Dryburgh, Neil Kirkland, Kirsten Shouler, and Kim Sinclair-with Sinclair receiving an Oscar for his work on the blockbuster movie Avatar (“Kim Sinclair” n.d.).

In an analysis of Australian student graduation data from 1987 to 2013, I extrapolated an approximate figure for the percentage of first years who do not graduate to be around 40\% (Matthewson 2017: 174). The 36\% non-graduation rate for the first-year class of 1976 is a little lower than that figure. This may be due partly to the structure of the degree in New Zealand during the 1970s being different from that of Australia (intermediate year plus four professional years at the Auckland School compared with generally a full five years at a school of architecture in Australia). Mainly, however, in the Australian calculation I assumed that the degree is completed within a defined number of years, as I compared first-year numbers to graduation numbers a set number of years later. While I acknowledged that this makes it a very approximate calculation because this is seldom the case, the first-year class of 1976 clearly demonstrates just how seldom this happens and therefore how approximate that calculation is. The individuals in the class graduated over a period of five years.

Only just over half of the 1976 first-year cohort (55\%) completed the degree in the minimum numbers of years, with their degrees conferred in 1980 (26 of the 47), 11 graduated a year later, three the following year, four the next, two were conferred in 1984, and one outlier finally graduated in 1994. This dispersal pattern appears to be similar for others listed in the 1976 contacts booklet: $68 \%$ of second years completed the degree in the minimum number 
of years for their stage of study. Even for the third-year students, who had just two years to go, nearly one-quarter of them (24\%) took longer. This "stretching out" of graduation for architecture cohorts complicates the calculations of the Australian data.

Perhaps the best illustration of that complication comes when examining the 47 graduates from the first year of 1976 by gender. Women were eventually a high $34 \%$, or 16 of the 47 , of the first-year cohort who graduated, but measured as a proportion of each graduating year, women did not reach over 30\% until the mid-1990s (see Fig. 2). This was partly because the 1976 intake level of nearly one-third women was not matched in the immediate following years, as previously noted. And partly because women over this period took longer than men to complete the course of study. Table 1 shows how for almost every year group listed in the 1976, 1978, and 1980 contacts booklets, and the School overall, a lesser proportion of the women completed within the minimum time than the men. This was not necessarily due to failure (although it was for eight of the women in the 1976 first-year cohort), but also to taking time out. That more of the women seemed to do this than the men is another sign that things were awry for women in the School at that time. They were, perhaps, taking a breather from the world of "old heavy breathers".

Table 1: Completion within the minimum number of years, by gender, for graduating students listed in the 1976, 1978, and 1980 contacts booklets.

\begin{tabular}{|c|c|c|c|c|c|c|c|c|c|c|c|c|c|c|c|}
\hline & & ${ }^{\text {st }} \mathrm{Ye}$ & & & ${ }^{n d} Y e$ & & & ${ }^{\text {rd }} \mathrm{Ye}$ & & & $1^{\text {th }} Y e a$ & & & I sch & \\
\hline & $M$ & $\mathrm{~F}$ & Total & $M$ & $\mathrm{~F}$ & Total & $M$ & $\mathrm{~F}$ & Total & $M$ & $\mathrm{~F}$ & Total & $M$ & $\mathrm{~F}$ & Total \\
\hline 1976 & $61 \%$ & $44 \%$ & $55 \%$ & $74 \%$ & $42 \%$ & $68 \%$ & $76 \%$ & $75 \%$ & $76 \%$ & $92 \%$ & $100 \%$ & $93 \%$ & $78 \%$ & $62 \%$ & $75 \%$ \\
\hline 1978 & $43 \%$ & $38 \%$ & $42 \%$ & $31 \%$ & $44 \%$ & $33 \%$ & $81 \%$ & $57 \%$ & $74 \%$ & $93 \%$ & $100 \%$ & $94 \%$ & $64 \%$ & $60 \%$ & $63 \%$ \\
\hline 1980 & $38 \%$ & $42 \%$ & $39 \%$ & $50 \%$ & $43 \%$ & $49 \%$ & $60 \%$ & $58 \%$ & $59 \%$ & $85 \%$ & $60 \%$ & $80 \%$ & $58 \%$ & $51 \%$ & $57 \%$ \\
\hline
\end{tabular}

In fact, the women in the original 1976 first-year class were slightly more successful at graduating than their male classmates. They comprised $34 \%$ of all those who eventually graduated but were $32 \%$ of the class in 1976. I did not expect this result because multiple studies have maintained that more women than men dropped out of architecture study, particularly at this time, due to harassment, gender bias, and discrimination (Ahrentzen \& Anthony 1993; Anthony 2001; Shannon 1996). The Australian data I analysed also strongly suggest greater attrition for women students of architecture: the difference between the proportion of female first years who do not graduate averages out at between $3.5 \%$ and $4 \%$ higher than the males (Matthewson 2017: 174). If women were simply taking longer to complete the degree, then perhaps the attrition of women was not as severe as these earlier studies, and my more recent analysis, suggested.

There are, however, several caveats to this interpretation. First, small numbers can create instability in generating percentages. Second, the women of the class of 1976 may have been a particularly tenacious group, but they also had some advantages over previous groups of women at the School. Within their cohort they comprised $32 \%$, comfortably over the commonly touted critical mass figure of $30 \%$ that marks a shift in culture, reducing isolation and discrimination. Drude Dahlerup argues that the concept of a "critical mass" of women representing a definitive tipping point is debatable, but the principles that more women 
reduces isolation and that negative stereotypes lose some of their potency still pertain (Dahlerup 2006). Third, and importantly, the cohort had the example of some particularly strong women as role models in the years above them, notably Fiona Christeller and Amanda Reynolds. Role models are crucial for naturalising the presence of women in a profession or holding a particular position (Ely, Ibarra, \& Kolb 2011: 477). In 1979, Reynolds and Christeller along with '76 cohort member Janet Thomson also battled misogyny in the School and the profession head-on by setting up the Women's Institute of Architecture (Matthewson 2009; McKay 2017: 92). Finally, looking at all the women who were in the School in 1976 (rather than the smaller number in the first-year cohort), although they did indeed take longer to complete, fewer of them overall did so. Of the 310 students, 56 (or $18 \%$ ) did not graduate; $23 \%$ of the women and $17 \%$ of the men. Effectively, women tallied $21 \%$ of the School in 1976 , but $19.7 \%$ of all those who eventually graduated. Both calculations demonstrate a higher attrition rate for the women students. For the 1978 contacts booklet, women comprised $19.1 \%$ of the graduates and $20.9 \%$ of those who were gender-identifiable in the School, again indicating a higher attrition rate for women students (there are too many in the 1980 booklet that I am unable to gender-identify to do the calculation for that year).

Notwithstanding the attrition rate of all architectural students (not just the women), the number of graduates per year heading out into the population rose over the 1970 s and continued to rise. Around 1970 there were 40 graduates a year, for a population of 2.85 million, giving a rate of 1.4 for every 100,000 people and women were just 0.02 of that 1.4 figure (Statistics New Zealand 2017; University of Auckland 1959-1994). By 1980, there were 70 graduates per year (including those from Victoria University of Wellington) generating a 2.3 rate (women 0.5, and men 1.8). The rate for 1990 was 2.9 (women 0.8), and currently sits at around 4.0 with that figure almost evenly split between men and women (Australian Institute of Architects 2015). While women have increased their impact on this figure, men have stayed relatively stable-a similar result to Australia where women graduates have accounted for most of the growth of architectural graduates relative to the population (Matthewson 2017: 172).

So what happened to the 47 graduates? Where did they go? And what did they do with their architectural education?

\section{Registration}

Registration or the license to practise architecture is one of the few measurements of participation in the profession. It is a rather crude measure because it is possible to work in architecture and not be registered-it is only required legally for calling oneself an architect and running a practice in New Zealand, as is the case in Australia and the United Kingdom. Registration also does not track the alternate routes that those who study architecture can find open up to them across their careers. Nonetheless, a study of registration helps to delineate what happened to some of the class of '76. Of the 47 graduates, 26 (55\%) have New Zealand registration (NZRAB n.d.), although four have relinquished it. ${ }^{2}$ Another seven can call themselves architects in the United Kingdom or Australia (ARB-NSW n.d.; ARB-UK n.d.; ARBV n.d.; BOAQ n.d.).

The cohort's level of 55\% registered in New Zealand is higher than the rate that others have calculated. In 2010, Errol Haarhoff tracked every graduate from New 
Zealand architecture schools between 1987 and 1999 and found an average rate of $38 \%$ registration for those who graduated; no single graduation year exceeded 50\% (Haarhoff 2010: 18). This figure is higher but similar to registration rates found for Australian graduates: in New South Wales, Rob Cowdroy concludes that "the proportion of graduates eventually registering is unlikely to reach thirty percent" (Cowdroy 1995: 12). And a recent South Australian study found a $26 \%$ registration rate for all graduates in that state from 1999 to 2011 (Shannon, Webb, Zeng, \& Holder 2014: 1544).

Was the class of '76 more committed to obtaining the title of architect and participating in the profession in this formal way? To answer that question requires considering the registration data further back than Haarhoff's date of 1987. Fig. 4 plots the percentage of each graduating cohort from the Auckland School of Architecture who registered under the Architects Act 1963 and shows overall declining rates of registration for graduating cohorts since the beginning of the data in the 1960s. Until the mid-1970s, well over 70\% of Auckland graduates registered. For the next decade until the mid-1980s, the average was over $60 \%$. This means that at 55\% registered, the first-year class of 1976 was actually below the average for graduating cohorts of the decade. It is also below that for all the graduates listed in the 1976 booklet, 62\% of whom registered. In comparison, 63\% of all graduates from the 1978 booklet and $68 \%$ from the 1980 booklet registered. Fig. 4 shows the registration rate dropping again for those who graduated in the mid-to-late 1980s, perhaps due to the registration process changing to include logbooks in addition to the traditional interview. The trajectory overall continues down for the rest of the century.

This declining rate of registration for graduates is undoubtedly affected by the increasing number of graduates per head of population (discussed earlier), as well as the changing nature of the profession where the increasing dominance of large firms (Cuff 2014) means that registration is less important for employees. In addition, perceptions of the importance of registration vary among graduates (Shannon et al. 2014: 1548-49).

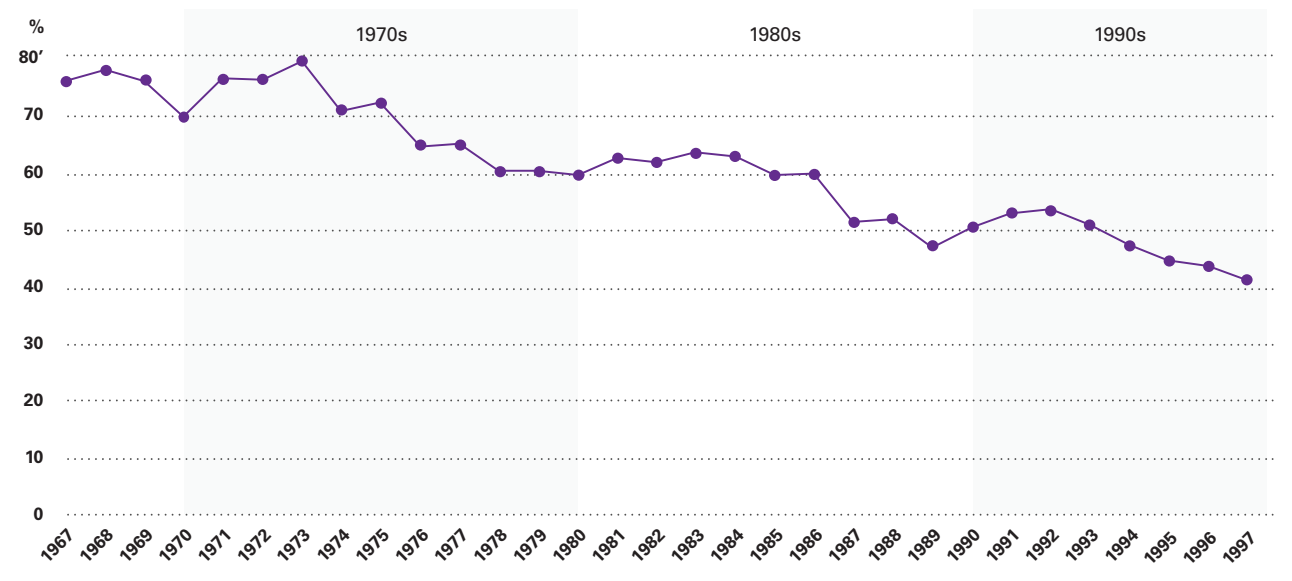

Fig. 4 Percentage of Auckland graduates registered under the New Zealand Architects Act 1963. Data smoothed by taking the average of prior three years. [Source: NZRAB (n.d.)]
There is some discrepancy between the Fig. 4 figures and those of Haarhoff's study, partly because he aggregated all the New Zealand schools, and partly because graduates can become registered many years after graduating; a period of working overseas, for example, might delay New Zealand registration. For the class of '76, over half (14) of those who registered had done so within five years, 
but four took longer than 10 years. Typically for graduates in the 1970s and 1980s, around two-thirds registered within five years, and less than $10 \%$ took longer than 10 years. The cohort of ' 76 deviates from this pattern, generally taking longer. However, with small numbers (just 26) such deviation does not necessarily signify much.

The gender breakdown is curious-half of the 14 who registered within five years were women. There were two lines of thought at the time about registration that I recall. One was that to register was to "sell out" and conform to an old-fashioned, conservative, and oppressive vision of architectural practice-another hangover from a certain kind of anti-authoritarianism prevalent at the time and a serious will to practise in a non-exploitative manner (Francis 2016: 282; McKay 2017; Shannon 1996: 58). The second (and opposing) line of thought was strong among women graduates: an impetus to register in order to boost the ranks (the military analogy is deliberate) at a time when there were strong doubts that women could or should be architects (Matthewson 2009). Clearly, some of the women of the class of '76 heeded that call. Nonetheless, the two taking the longest time to register were both women. For all those who graduated between 1965 and 1997, a bare $1 \%$ of graduates registering took longer than 20 years, and women comprised one-third of that $1 \%$. Just as women took longer to complete their studies, some took longer to become registered. Speed of graduating or registering is less an indication of "success" or otherwise for the graduates, but that women typically took longer at both does indicate that they faced barriers to becoming architects.

There is also typically a gender difference in the overall attainment of registration. From 1965 to 1997, women constituted $20 \%$ of graduates $(405$ of 1,992$)$ but $15 \%$ of all those graduates who registered (169 of 1,151); $62 \%$ of all the male graduates over that period registered, compared with $42 \%$ of the females. This repeats the findings from both Haarhoff (2010: 23) and Shannon et al. (2014: 1544) that women are significantly less likely to register than men. The latter study delved into reasons why women were more hesitant to register and found that gender bias in the profession and the construction industry contributed. Such biases may be less blatant in the twenty-first century than in the period in which the class of '76 graduated (Matthewson 2009), but nonetheless continue to contribute to women being less likely to register.

Curiously, the women in the class of ' 76 make up 38\% of those of the cohort who registered. This is again a higher proportion than expected. But again, this is measuring against a first-year intake cohort (and generated with small numbers). Over the period of time that all but one of the cohort graduated (1980-84), the proportion of women graduating averaged 18\% (279 graduates, 49 female). Over the same period, women's percentage of those graduates who registered was $13 \%$ (173 registered, 23 women). Once again, the high proportion of women in the first-year class of '76 who went on to register is not reflected in an analysis of the graduating cohorts. The year was clearly anomalous for the number of women and also for their eventual success as measured by graduation and registration.

\section{Lives in Architecture}

Registration is a formal measurement and gives no indication of the wide variety of lives in-and stemming from-architecture of the 47 graduates from the class 
of '76. These lives are more difficult to trace and I have relied on email addresses from the New Zealand Registered Architects Board (NZRAB) register, Google, and the recall of those acknowledged at the end of this paper. This kind of search also raises questions such as what does success in architecture mean, and what ought a career look like compared to what it does look like.

Like those who did not graduate, some graduates used their architecture education to launch into other often related fields. Alan Brown became a painter and printmaker as well as architect ("Alan Brown” n.d.), Rob Morrison was a project manager with the New South Wales Government (R. Morrison, personal communication, August 28, 2017), and Paul Hamilton "looks after" a self-contained oil-company town in Bahrain dealing with everything from rubbish collection to the water supply, security issues to new buildings, and houses to hospitals ( $\mathrm{P}$. Hamilton, personal communication, July 2, 2017). Anna Kemble Welch mixes standard architectural work with organising Wellington's Newtown Festival, the largest community festival in the country, and considers building community to be as much architecture as designing and constructing buildings (A. Kemble Welch, personal communication, July 11, 2017).

Geographically, the graduates are spread across the world. Although nearly half worked overseas at some stage, some of those returned to New Zealand and twothirds are now based in the country that educated them. There is a cluster of seven in Australia, two in the Middle East, two in Europe, and one in the United States. Some have been involved with formal matters concerning architects: Pip Cheshire was president of the New Zealand Institute of Architects (NZIA) from 2014 to 2016; Simon Crispe established the Arabian Gulf Chapter of the Royal Institute of British Architects and was the first chair of the chapter (S. Crispe, personal communication, August 16, 2017); and Jane Aimer was the last chair of the Architects Education Registration Board prior to its disestablishment in the mid-2000s.

The majority of those whose lives I have been able to trace are still in architecture in some way: 29 in practice (nine women and 20 men) and four in architectural education (three women, one man). I have been unable to track six, three have died, and one retired. Just three no longer work in architecture, leaving during one of the all-too-numerous economic slumps that have occurred since their graduation (including the one into which the majority of the cohort graduated in the early 1980s). It appears that only one never used the degree in any direct way since graduation, although she argues that her architectural training and skills were useful in the other fields she ventured into (J. Thompson, personal communication, July 4, 2017).

Over $70 \%$ of the graduates opted to become architects in the more formal sense through registration (if overseas registration is included), but their practices range widely demonstrating the breadth of possible careers within architecture. Of the 29 graduates of the class of ' 76 who are still in some form of practice, 20 are directors of their own practices (including six women) and these range from small local ones to very large international firms. Eight of the cohort's businesses have three or fewer in the practice, five consist of four to nine people, three of 10 to 15 people, two of 16 to 30, and two in excess of 100 employees. There are no women owners of practices of more than 16 people-this spread is typical as women owners tend to cluster in smaller practices (Civil 2016; Parlour 2017). 
Eight of the practices owned by the class of '76 are named after their owners, either by their full name or surname only-a long-held naming tradition in architecture. But this convention was challenged in the 1970s-along with much else-and some formed collectives, while others have selected names that bear no relation to that of the owner/s. Nine of the cohort are owner/directors in such practices, including Graeme Fanselow of Fat Parrot, Anna Kemble Welch of Red Design Architects, John Leijh of Architos, and Jane Aimer and Lindley Naismith of Scarlet Architects. Another three have become directors of large older firms that retain the names of their founders, a sign of stability and continuity important for the kind of clients that large practices serve. There are two routes to this outcome. One is by moving up the hierarchy, such as Chris Bowkett at Walker Group Architects and Simon Crispe at Atkins Global. The other is by being parachuted in from a small, usually award-winning practice, a kind of head-hunting by the larger firms to refresh design talent, as was the case for Andrew Barclay at Warren \& Mahoney Architects.

Dana Cuff calls working for oneself the "guiding vision" for architects (Cuff 1991: 137), as this gives access to the mechanisms the profession uses to reward architectural work: awards and media. The most successful of the '76 cohort in these terms is Pip Cheshire, who has the highest architecture profile within New Zealand. He is a multi-award-winning designer and the recipient of the NZIA Gold Medal in 2013 (NZIA n.d.). The work of his practice appears in a number of books about New Zealand architecture (Lloyd Jenkins 2004: 253, 256, 276-79; Shaw 1991: 193-94, 210-11, 226; Walker 2005: 217), and he has written one himself (Cheshire \& Reynolds 2008).

However, Mal Bartleet was the first of the '76 cohort to have built work appear in a book, The Elegant Shed, published a scant four years after his graduation (Mitchell \& Chaplin 1984: 100). Bartleet, Cheshire, Barclay, and Richard Priest all appear in Douglas Lloyd Jenkins' romp through twentieth-century New Zealand design, At Home: A Century of New Zealand Design (2004).

Cheshire's career (and that of some of the others named above) adheres to the classic "ideal" image of an architect as a single person of outstanding design ability and vision, author of work that is identified and published as his. It is an ideal that is promoted by architectural history, award systems, and the media, but it is both fraught and anachronistic for many reasons (Boyle 2000: 90; Willis 1998). It is not the norm for an architectural career, as many of the class of '76 demonstrate. Much of the work of architects gains no public plaudits or publication of any kind and extends beyond the well-publicised and glamorous scenarios of starchitects or award systems. It is nonetheless a powerful and persistent narrative and reared its head when some of the ' 76 first-year cohort seemed a little reluctant to talk to me, aware that their life in architecture did not match that narrow ideal.

Another from the cohort forged an alternate route towards recognition in the architectural world in a manner that was uncommon at the time of graduation. Mark Wigley has international renown as Professor of Architecture and former Dean at the Columbia University Graduate School of Architecture, Planning and Preservation in New York (Faculty n.d.). Within eight years of graduating with his Bachelor of Architecture (and with a $\mathrm{PhD}$ also from Auckland under his belt), Wigley was in New York co-curating with Philip Johnson the influential 
Deconstructivist Architecture exhibition at the Museum of Modern Art (Johnson \& Wigley 1988). In the early 1980s, postgraduate study was only just beginning to be seen as an option by graduates (McKay 2017: 98). Wigley is well-published and an often-cited architectural theorist, and has influenced generations of architecture students both nationally and internationally (Barrie 2017: 114). Another three of the cohort-Diane Burgess, Diane Brand, and myself-entered academia, although after a period in practice, and, like Wigley, are concerned with improving the quality of architecture through shaping the education of architects.

Some of the cohort have not followed either this or the established route that leads to traditional architectural acknowledgement, as nearly one-third (nine) of those from the cohort who are in practice are employees, not owners. There are risks and obligations involved in ownership with which not all architects are comfortable. Ownership involves hustling for work in a highly competitive environment. Or it can be a role that is typically more about management than architecture. Matt Adams characterised his ownership role in a practice with five employees as "dogsbody, run-around and gap-filler" (M. Adams, personal communication, July 6, 2017). At the other end of the scale, Simon Crispe claimed his role was mainly wrangling staff of over 2,500 construction professionals (S. Crispe, personal communication, August 16, 2017).

Instead, those of the graduate cohort who are employees are to be found at the next level down from ownership in trusted associate positions typically in medium to larger sized firms. Such firms tend to offer the opportunity to work on challenging and interesting projects, "getting things done". Morgan McKewen described himself as an "engine room" person (M. McKewen, personal communication, June 29, 2017). The practise of architecture at this level, particularly of ushering in a built work with all its complex problem solving, can lead to rewards other than awards, publication, or identifiable authorship. These include the satisfaction of contributing to important buildings, a sense of adding to society, and the formation of social relationships with others (Caven \& Diop 2012).

Architectural sociologist Paul Jones argues that the work of the architecture profession is incredibly diverse, but culturally the profession valorises just one aspect of what architects do (Jones 2009: 2523). The graduates of the first-year class of '76 show that diversity and in doing so reveal the narrowness of the "ideal" image of an architect as the identifiable singular author of work. There is much talk about the expanded field of architecture-architecture is already expansive, it is just that, collectively, but the profession values a small portion of it.

Given that part of the aim of the 1972 protest at the School was to open up architectural education from its intense professional focus, the high number of those who graduated from the class of ' 76 who are still strongly connected to the architecture profession, suggests that perhaps the opportunities offered by this "looser" education were not taken up. Yet the variety of practices that the graduates encompass is very wide (perhaps even very loose), ranging greatly not just in size but from the corporate to the community-focused. And if we look at that number (33) compared to the original class of 74 , less than half remain in the field. This has implications for architectural education-if less than half of a cohort stay in traditional practice, then how a school understands and communicates what the profession is has lasting ramifications. There have always been tensions between schools and the profession, and probably always will be, 
but the class of ' 76 demonstrates the sheer breadth of the range of options, both within the profession and outside of it, with which those with an architectural education engage.

\section{Conclusion}

Narrowing the focus onto one class of first-year students or those who were enrolled in a particular year allows a relatively fine-grained examination of what happens to those who study architecture. However, it can also throw up anomalies because small numbers can cause statistical aberrations and a year group is not necessarily representative of a time period. For example, the 1976 intake saw significantly more women enter the school than in previous or subsequent years and these women were comparatively successful in terms of the formal measurements of graduation and registration.

As a group, the class of first-year students in the Auckland School of Architecture in 1976 demonstrates the high fall-out rate while studying. The women of the group were slightly more tenacious than the men and proportionally more of them graduated, but this was not typical for the period. They did, however, take longer to complete, which was typical. After graduation, the class of ' 76 shows the wide variety of possible lives in architecture. Some have come close to the "ideal" of the acknowledged architect of known (at least in New Zealand) buildings, but the cohort reveals much more of the wide diversity possible in architecture well beyond that ideal. All those in practice have applied their architectural thinking to their work across a wide range of buildings in New Zealand and across the world. And those who did not graduate, and some of those who did, have used their education in ways other than traditional practice.

Overall, the class of '76 is loosely of its "loose" time. It was also a time when graduates were rarer in the population than they are currently, which means that the statistics and lives of those in the cohort cannot be extrapolated to represent all those who have passed, or may pass, through an architecture school. But the cohort does highlight some of the issues that still confront those who choose architecture as an education and a career.

\section{Acknowledgements}

For their input into this article, I thank Matt Adams, Jane Aimer, Sara Antonievich, Andrew Barclay, Mal Bartleet, Diane Brand, Pip Cheshire, Simon Crispe, Graeme Fanselow, Paul Hamilton, Heather Ives, Anna Kemble Welch, Lyn Maltby, Morgan McKewen, Rob Morrison, Lindley Naismith, Roger Thackery, Janet Thomson, Lucy Treep, Stephen Ullrich, and Paul Walker. 


\section{REFERENCES}

Ahrentzen, S., \& Anthony, K. H. (1993). Sex, stars, and studios: A look at gendered educational practices in architecture. Journal of Architectural Education, 47(1), 11-29. Retrieved from http://www. istor.org/stable/1425224

Alan Brown. (n.d.). Design \& art Australia online. Retrieved from https://www.daao.org.au/bio/alanv-brown/personal_details/

Anthony, K. H. (2001). Designing for diversity: Gender, race, and ethnicity in the architectural profession. Urbana \& Chicago, IL: University of Illinois Press.

\section{ENDNOTES}

\section{${ }^{1} \mathrm{G}$. Fletcher (personal} communication, September 10, 2017) denied that the cover might be a caricature of a member of staff, but every female student I have spoken to from that period is convinced otherwise.

${ }^{2}$ The NZRAB website lists all those who have ever been registered in New Zealand.

ARB-NSW. (n.d.). New South Wales Architects Registration Board. Retrieved from https:// www.architects.nsw.gov.au/

ARB-UK. (n.d.). Architects Registration Board. Retrieved from http://architects-register. org.uk/

\section{ARBV. (n.d.). Architects}

Registration Board of Victoria. Retrieved from http://www.arbv. vic.gov.au/for-consumers/search the-register/

Auckland School of Architecture (1976). Old Heavy Breather Network/Annual [Student handout]. Copy in possession of author.

Auckland School of Architecture (1978). Phone contacts [Student handout]. Copy supplied by L. Treep.

Auckland School of Architecture (1980). Phone contacts [Student handout]. Copy supplied by L. Treep.

Australian Institute of Architects. (2015). Architecture Schools of Australasia. Barton, ACT: Australian Institute of Architects National Office.

Barrie, A. (2017). "Architecture to a fault": The post-modern years. In J. Gatley \& L. Treep (Eds.), The Auckland School: 100 years of architecture and planning (pp. 102-127). Auckland: School of Architecture and Planning, University of Auckland.

BOAQ. (n.d.). Board of Architects of Queensland. Retrieved from https://www.boaq.qld.gov.au/ BOAQ/Search_Register/BOAQ/
Search_Register/Architect Search.aspx?hkey=b057ad1c2fc3-4b3b-9cc6-34d238b01569

Boyle, B. M. (2000). Architectural practice in America, 1865-1965: Ideal and reality. In S. Kostof (Ed.), The architect: Chapters in the history of the profession (pp. 309-344). Berkeley, CA: University of California Press.

Caven, V., \& Diop, M. (2012). Architecture: A "rewarding" career? An Anglo-French comparative study of intrinsic rewards in the architecture profession. Construction Management and Economics, 30(7), 513-523.

Cheshire, P., \& Reynolds, P. (2008). Architecture uncooked: The New Zealand holiday house through the architect's eye. Auckland: Godwit.

Civil, D. (2016). The pioneer class. Retrieved from http:// www.architecturewomen.org.nz/ archives/pioneer-class-denisecivil

Cowdroy, R. (Ed.) (1995). Architects' transition from graduation to registration. Sydney: The Board of Architects of New South Wales.

Cuff, D. (1991). Architecture: The story of practice. Cambridge, MA: MIT Press.

Cuff, D. (2014). Commentary: Architecture's undisciplined urban desire. Architectural Theory Review, 19(1), 92-97. doi:10 .1080/13264826.2014.899071.

Dahlerup, D. (2006). The story of the theory of critical mass. Politics and Gender, 2(4), 511-522. doi:10.1017/S1743923X0624114

Ely, R. J., lbarra, H., \& Kolb, D. M. (2011). Taking gender into account: Theory and design for women's leadership development programs. Academy of Management Learning and Education, 10(3), 474-493. doi:10.5465/amle.2010.0046

Faculty. (n.d.). Columbia GSAPP. Retrieved from https://www.arch columbia.edu/faculty/33-markwigley

Francis, K. (2016). Ether: An atmosphere of possibility. In K. James-Chakraborty (Ed.), Proceedings of the fourth international conference of the European Architectural
History Network (pp. 272-284). Dublin: UCD School of Art History and Cultural Policy. Retrieved from https://eahn.org/ app/uploads/2016/07/eahn_ proceedings_2016.pdf

Haarhoff, E. (2010). Practice and gender in architecture: $A$ survey of New Zealand architecture graduates, 1987-2008. Auckland: The University of Auckland.

Jackie Gilmore. (n.d.) Internet Movie Database. Retrieved from https://www.imdb.com/name/ $\underline{\mathrm{nm0319534/} \text { ?ref_=ttfc_fc_cr40 }}$

Johnson, P., \& Wigley, M. (1988). Deconstuctivist architecture. New York, NY: Museum of Modern Art.

Jones, P. (2009). Putting architecture in its social place: A cultural political economy of architecture. Urban

Studies, 46(12), 2519-36. doi:10.1177/0042098009344230

Jones, S. M. (2011). Teachers and tipping points: Historical origins of the teacher quality crisis. In P. W. Rhode, J. L. Rosenbloom, \& D. F. Weiman (Eds.), Economic evolution and revolution in historical time (pp. 336-356). Stanford, CA: Stanford University Press.

Kim Sinclair. (n.d.) Internet Movie Database. Retrieved from http://www.imdb.com/name/ nm0801662/

Lloyd Jenkins, D. (2004). At home: A century of New Zealand design. Auckland: Random House.

Matthewson, G. (2009). You have no idea: Women in architecture in the eighties. In C. McCarthy (Ed.),

“... ponderous pedantic pediments prevail ... good, clean fun in a bad, dirty world": New Zealand architecture in the 1980s (pp. 5761). Wellington: Centre for Building Performance Research, Faculty of Architecture and Design, Victoria University of Wellington.

Matthewson, G. (2010). House work: Women and the Group. In J. Gatley (Ed.), Group Architects: Towards a New Zealand architecture (pp. 178-183). Auckland: Auckland University Press.

Matthewson, G. (2017). The gendered attrition of architects in Australia. arq-Architectural Research Quarterly, 21(2), 171-82. https://doi.org/10.1017/ S1359135517000367 
McKay, B. (2017). The counterculture and its containment:

The loose years. In J. Gatley \& L. Treep (Eds.), The Auckland School: 100 years of architecture and planning (pp. 74-101).

Auckland: School of Architecture and Planning, University of Auckland.

McLeod, M. (2012). The end of innocence: From political activism to postmodernism. In J. Ockman \& R. Williamson (Eds.), Architecture School: Three centuries of educating architects in North America (pp. 160-201). Cambridge MA: MIT Press \& Association of Collegiate Schools of Architecture.

Mirza and Nacey Research. (2017). RIBA Education Statistics 2015/16. Retrieved from https:// www.architecture.com/-/media/ gathercontent/educationstatistics/additional-documents/ educationstatistics201516pdf.pdf

Mitchell, D., \& Chaplin, G. (1984). The elegant shed: New Zealand architecture since 1945. Auckland: Oxford University Press.

NZIA. (n.d.). The NZIA Gold Medal. Retrieved from https://www.nzia. co.nz/awards/gold-medal

NZRAB. (n.d.). The New Zealand Architects Register. Retrieved from https://www.nzrab.nz/ Search/

Parlour. (2017). The numbers in a nutshell: Women in architecture, Australia. Retrieved from http:// archiparlour.org/wp-content/ uploads/2017/06/Numbers-in-aNutshell-2.pdf

Shannon, S. (1996). Architecture and equity: Education and practice. Architectural Theory Review, 1(1), 48-62.

Shannon, S., Webb, N., Zeng, Y., \& Holder, J. (2014). Why architecture graduates do not register as architects: A quantitative and qualitative South Australian study, 1999-2011. Creative Education, 5. Retrieved from http://www.scirp. org/journal/ce

Shaw, P. (1991). New Zealand architecture: From Polynesian beginnings to 1990. Auckland: Hodder Moa Beckett.

Statistics New Zealand. (2017). Population of New Zealand. Retrieved from http://archive. stats.govt.nz/browse for_stats/ population/estimates and projections/historical-populationtables.aspx

Stevens, G. (2014). Women in architecture 2: Squish those big swinging dicks. Retrieved from http://www.archsoc.com/kcas/ ArchWomen2.html

Stratigakos, D. (2016). Where are the women architects? New York, NY: Princeton University Press.

Sunday male. (1976, August 15) Sunday News, p. 4.

Twose, H. (2015, May 22).

Executive success: It took a while to get up to steam. New Zealand Herald. Retrieved from http://www.nzherald.co.nz/ business/news/article.cfm?c id=3\&objectid=11452604

University of Auckland. (1961). The University of Auckland, Calendar 1961. Auckland: Whitcombe and Tombs Ltd.

University of Auckland. (1969).

The University of Auckland,

Calendar 1970. Auckland:

Whitcombe and Tombs Ltd.

University of Auckland. (1970).

The University of Auckland,

Calendar 1971. Auckland:

Whitcombe and Tombs Ltd.

University of Auckland. (1976).

The University of Auckland,

Calendar 1976. Auckland:

Whitcombe and Tombs Ltd.

University of Auckland. (1959-1994). Convocation for the Conferment of Degrees and Diplomas, 1959-1994.

University passes, studio I 15.410.

(1976, December 6). New Zealand Herald, p. A11.

University passes, studio III 15.412. (1976, December 8). New Zealand Herald, pp. A1, A11.

University passes, studio 3 15.301. (1978, December 14). New Zealand Herald, p. A10.

University passes, studio 3 15.301. (1980, December 19). New Zealand Herald, p. B6.

Untitled. (1976, August 9). The Auckland Star, p. 5.

Victoria University. (1983).

Victoria University of Wellington, Calendar 1983. Auckland: Whitcoulls.

Victoria University. (1984). Victoria University of Wellington, Calendar 1984. Auckland: Whitcoulls.
Walker, C. (Ed.). (2005). Exquisite apart: 100 years of architecture in New Zealand. Auckland: Balasoglou Books, for the New Zealand Institute of Architects.

Willis, J. (1998). Invisible contributions: The problem of history and women architects. Architectural Theory Review, 3(2), 57-68. 